\title{
Hubungan Riwayat Usia Penyapihan dengan Status Gizi Usia 24-36 Bulan
}

\author{
Jenie Palupi ${ }^{1}$, Syiska Atik ${ }^{2 *}$ \\ ${ }^{1)}$ Program Studi Kebidanan Jember, Politeknik Kesehatan Kemenkes Malang,yoga_jenie@yahoo.com \\ ${ }^{2}$ Program Studi Kebidanan Jember, Politeknik Kesehatan Kemenkes Malang, \\ syiskahermawan.1978@gmail.com
}

\begin{abstract}
ABSTRAK
Usia penyapihan adalah waktu pemberhentian ASI dan diganti dengan makanan pendamping ASI. Berdasarkan studi pendahuluan di Posyandu Aster Kelurahan Tegal Besar Kecamatan Kaliwates Kabupaten Jember dari 10 orang responden ibu yang memiliki anak usia 24-36 bulan yang telah menyapih anaknya hanya 2 orang yang tepat waktu dan status gizi anaknya baik, dan 8 orang yang melakukan penyapihan tidak tepat waktu. Tujuan penelitian ini untuk mengetahui Hubungan Riwayat Usia Penyapihan dengan Status Gizi Anak usia 24-36 bulan. Desain penelitian analitik korelasi dengan pendekatan cross sectional. Populasi 128 ibu yang memiliki anak usia 24-36 bulan, sampel 96. Tekhnik yang digunakan simple random sampling secara kocokan dengan pengumpulan data menggunakan kuisioner diperoleh penyapihan usia $\geq 24$ bulan sebanyak 28(29,16\%), $<24$ bulan sebanyak 68 (70,84\%). Status gizi lebih sebanyak 13(13,54\%), baik sebanyak 26 (27,08\%), kurang sebanyak 42 (43,75\%), buruk sebanyak 15 (15,62\%). Berdasarkan uji statitik Chi Square dan $d k=1$ serta taraf kesalahan $5 \%$ didapatkan $x^{2}$ hitung lebih besar dari $x^{2}$ tabel $(9,12>3,481)$ dan KK sebesar 0,295. Kesimpulan ada hubungan antara riwayat usia penyapihan dengan status gizi anak usia 24-36 bulan dengan kekuatan hubungan rendah/ lemah tapi pasti. Petugas kesehatan hendaknya memberikan penyuluhan tentang penyapihan yang tepat dan dampak penyapihan yang tidak tepat sehingga masyarakat tidak melakukan penyapihan yang tidak tepat pada waktunya.
\end{abstract}

Kata kunci: Status Gizi, Penyapihan, Tepat Waktu

\begin{abstract}
Weaning age is the time when breastfeeding is stopped and replaced with complementary foods. Based on a preliminary study at the Posyandu Aster, Tegal Besar Village, Kaliwates District, Jember Regency, of the 10 respondents who had children aged 24-36 months who had weaned their children, only 2 were on time and the nutritional status of their children was good, and 8 people who did the weaning incorrectlytime. The purpose of this study was to determine the relationship between the history of weaning age and the nutritional status of children aged 24-36 months. Correlation analytic research design with cross sectional approach. The population is 128 mom who have children aged 24-36 months, the sample is 96. The technique used is simple random sampling with data collection using questionnaires, obtained $=24$ month weaning age as 28(29.16\%), <24 months were 68 (70.84\%). Nutritional status over 13 (13.54\%), both were 26 (27,08\%), approximately as many as 42 (43.75\%), poor as many as 15 (15.62\%). Statistically Based on Chi Square test and $d f=1$ and the $5 \%$ error level obtained $x 2$ count is greater than $x 2$ tables $(9.12>3.481)$ and KK forb 0,295. The conclusion is that there is a relationship between the history of weaning age and the nutritional status of children aged 24-36 months with a low/ weak but definite relationship strength. Health care workers should provide education on properweaning and weaning effects of improper weaning so that people do right on time.
\end{abstract}

Keywords: Nutritional Status, Weaning, Right On Time

*Author Correspond: Syiska Atik, Program Studi Kebidanan Jember, Politeknik Kesehatan Kemenkes Malang, e-mail : syiskahermawan.1978@gmail.com,HP.082141017317

\section{PENDAHULUAN}

Menyapih adalah suatu proses berhentinya masa menyusui secara berangsur angsur dan sekaligus. Proses tersebut dapat disebabkab oleh berhentinya sang anak dari menyusu pada ibunya atau juga berhentinya sang ibu menyusui anaknya, atau dari keduanya dengan berbagai alasan. Indonesia menganjurkan memberi ASI kepada bayi sampai dengan umur 2 tahun.

Kandungan ASI sangatlah luar biasa, selain memiliki nutrisi dan vitamin yang 
dibutuhkan dalam proses pertumbuhan dan perkembangan, ASI juga memiliki zat protektif dan antibodi yang dapat membantu kekebalan bayi, meningkatkan kecerdasan dan mempunyai efek psikologis yang menghubungkan antara anak dan orang tuanya.

ASI sangat higienis dan memiliki konsentrasi pertumbuhan yang sangat tinggi dan sistem kekebalan tubuh yang baik, dan beberapa kandungan ASI yang tidak terdapat pada susu formula yang mana kandungan ini sangat baik bagi kehidupan bayi seperti zat imunologik dimana zat ini berfungsi sebagai antiinfeksi yang bersih dan bebas kontaminasi. Zat imun ini terdapat pada immunoglobulin, secretor, dan laktoferin serta adanya faktor bifidus yang dapat merangsang lactobacillus bifidus untuk melindungi saluran pencernaan. ${ }^{1}$ Faktor inilah yang mengurangi kejadian banyak penyakit di masa kecil dan masa dewasa, dan juga memberi manfaat pada kesehatan ibu. ${ }^{2}$

Menurut beberapa penelitian komposisi ASI terus berubah hingga anak usia 2 tahun dan masih tetap mengandung nutrisi penting yang membangun sistem kekebalan tubuh anak. Beberapa zat imun meningkat jumlahnya dalam ASI di tahun kedua sehingga memberikan perlindungan yang lebih besar bagi anak, pada tahun kedua (12-24 bulan), setiap $448 \mathrm{ml}$ ASI memenuhi kebutuhan anak (energi 29\%), protein $43 \%$, kalsium $36 \%$, vitamin A $(75 \%)$, folat $(76 \%)$ vitamin b12 (94\%), dan vitamin c $60 \%$.

ASI merupakan makanan bayi yang paling baik dan ASI juga bermanfaat bagi tumbuh kembang bayi untuk lebih optimal. Akan tetapi ada kalanya oleh suatu sebab /, harus menambah atau mengganti ASI dengan makanan tambahan bahkan harus dilakukan penyapihan dini.

Berdasarkan data dari Kabupaten/Kota diketahui bahwa cakupan bayi yang mendapat ASI Eksklusif di Jawa Timur tahun 2018 sebesar $76.8 \%$. Cakupan tersebut mengalami kenaikan dibandingkan dengan tahun 2017 (75,7\%). Kenaikan tersebut menunjukkan semakin meningkatnya pemahaman para ibu bayi tentang pentingya ASI Eksklusif bagi bayi. Sebaliknya, sebanyak $23,2 \%$ bayi baru lahir mendapat makanan selain ASI selama 3 hari pertama. ${ }^{3}$ Sedangkan bayi usia 0-5 bulan yang masih menyusui mencapai $88,3 \%$ sedangkan usia 611 bulan $69,4 \%$. Balita Indonesia yang menderita gizi kurang dan gizi buruk $16,8 \%{ }^{4}$

Kekurangan Energi Protein (KEP) dapat terjadi karna para ibu yang setelah melahirkan, bekerja sehingga harus meninggalkan bayi dari pagi sampai sore, dengan demikian bayi tersebut tidak mendapatkan ASI yang merupakan nutrisi pokok disamping pemberian PASI atau makanan tambahan tidak diberikan sebagai mana mestinya. KEP dan infeksi mempunyai pengaruh timbal balik, merupakan masalah utama di Indonesia yang bila tidak ditanggulangi dengan baik akan mengganggu pembangunan sosial ekonomi dalam jangka pendek dan jangka panjang. Kedua masalah ini pada anak dibawah umur 2 tahun sangat erat hubungannya dengan menyusukan.

Fakor penyebab masalah tersebut adalah praktek penyapihan dini yang tidak tepat waktu (sebelum usia 2 tahun) serta kualitas makanan pendamping ASI yang tidak memadai. Tidak terpenuhinya nutrisi akan berpengaruh pada bayi dan balita sehingga timbul gizi kurang/ buruk.

Kabupaten Jember merupakan kabupaten dengan angka prevalensi balita Kekurangan Energi Protein (KEP) nomer tiga tertinggi di Provinsi Jawa Timur mencapai $25 \%$ pada tahun 2018. Angka gizi buruk Jember rata-rata lebih tinggi dibandingkan 35 Kabupaten dan kota yang tersebar di Jawa Timur. ${ }^{4}$

Berdasarkan studi pendahuluan di Posyandu Aster dari 10 orang responden ibu yang memiliki anak usia 24-36 bulan yang telah menyapih anaknya hanya 2 orang yang tepat waktu dan status gizi anaknya baik, dan 8 orang yang melakukan penyapihan tidak tepat waktu, dari 8 orang yang melakukan penyapihan tidak tepat waktu terdapat 2 orang anak status gizinya cukup, 3 orang anak status gizi kurang 2 orang status gizi lebih dan 1 orang status gizinya buruk.

Tujuan umum penelitian ini yaitu mengetahui apakah terdapat hubungan antara 
riwayat usia penyapihan dengan status gizi pada anak usia 24-36 bulan dan tujuan khususnya untuk mengetahui gambaran riwayat usia penyapihan dan status gizi.

\section{METODOLOGI}

Pada penelitian ini menggunakan metode analisis tentang suatu keadaan objektif dan digunakan untuk memecahkan atau menjawab permasalahan yang sedang dihadapi. Desain yang digunakan adalah analitik korelasional dan menggunakan pendekatan cross sectional yaitu rancangan penelitian dengan melakukan pengukuran atau pengamatan antara variabel 1 dan variabel 2 .

Populasi adalah semua ibu yang memiliki anak usia 24-36 bulan di Posyandu Aster yaitu sejumlah 128 ibu. Sampel adalah semua ibu yang memiliki anak usia 24-36 bulan sejumlah 96 ibu di Posyandu Aster yang memenuhi criteria inklusi. Dalam penelitian ini menggunakan Simple Random Sampling, yaitu teknik pengambilan anggota sampel dari populasi dilakukan secara acak dengan menggunakan kocokan nama tanpa memperhatikan strata yang ada dalam populasi itu. Alat ukur yang digunakan dalam penelitian ini terdiri dari kuisioner yaitu lembar isian yang dibagian pada responden yang menunjukkan usia penyapihan pada anak, timbangan, dan lembar NCHS

\section{HASIL DAN PEMBAHASAN}

Tabel 1. Distribusi Frekuensi Responden Berdasarkan Pendidikan Terakhir Ibu

\begin{tabular}{lcc}
\hline Pendidikan & $\Sigma$ Responden & Presentase \\
Terakhir Ibu & 64 & $66,7 \%$ \\
\hline Dasar & 28 & $29,16 \%$ \\
Menengah & 4 & $4,16 \%$ \\
Tinggi & 96 & $100 \%$ \\
\hline Total & & \\
\hline
\end{tabular}

Menunjukkan bahwa responden sebagian besar $(66,7 \%)$ berpendidikan sekolah dasar

Tabel 2. Distribusi Frekuensi Responden Berdasarkan Pekerjaan Ibu

\begin{tabular}{lcc}
\hline Pekerjaan Ibu & $\Sigma$ Responden & Presentase \\
\hline Tidak Bekerja & 73 & $76,04 \%$
\end{tabular}

\begin{tabular}{lcc} 
Pekerjaan Ibu & $\Sigma$ Responden & Presentase \\
\hline Swasta & 19 & $19,79 \%$ \\
Guru & 4 & $4,16 \%$ \\
\hline Total & 96 & $100 \%$ \\
\hline
\end{tabular}

Menunjukkan bahwa responden sebagian besar $(76,04 \%)$ tidak bekerja

Tabel 3. Distribusi Frekuensi Responden Berdasarkan Riwayat Kesehatan Anak

\begin{tabular}{lcc}
\hline Riwayat & $\Sigma$ Responden & Presentase \\
Kesehatan & 9 & $9,37 \%$ \\
Tidak Sakit & 87 & $90,63 \%$ \\
Sakit & 96 & $100 \%$ \\
\hline Total & \\
\hline
\end{tabular}

Menunjukkan bahwa responden sebagian besar $(90,63 \%)$ dengan riwayat anak sakit.

Tabel 4. Distribusi Responden

Berdasarkan Riwayat Usia Penyapihan

\begin{tabular}{lcc}
\hline Usia Penyapihan & $\Sigma$ Responden & Presentase \\
\hline$<24$ bulan & 68 & $70,84 \%$ \\
$\geq 24$ bulan & 28 & $29,16 \%$ \\
\hline Total & 96 & $100 \%$ \\
\hline
\end{tabular}

Menunjukkan bahwa hampir seluruh responden menyapih tidak tepat waktu, yaitu $68(70,84 \%)$

Tabel 5. Distribusi Responden

Berdasarkan Status Gizi Anak

\begin{tabular}{lcc}
\hline Status Gizi & $\Sigma$ Responden & Presentase \\
\hline Lebih & 13 & $13,54 \%$ \\
Baik & 26 & $27,08 \%$ \\
Kurang & 42 & $43,75 \%$ \\
Buruk & 15 & $15,62 \%$ \\
\hline Total & 96 & $100 \%$ \\
\hline
\end{tabular}

Menunjukkan bahwa hampir setengah responden memiliki status gizi kurang, yaitu 42 (43,75\%)

Tabel 6. Tabulasi Silang Hubungan Riwayat Usia Penyapihan dengan Status Gizi Anak Usia 24-36 Bulan

\begin{tabular}{lccccc}
\hline & \multicolumn{5}{c}{ Status Gizi } \\
Riwayat Usia & \multicolumn{5}{c}{ Total } \\
\cline { 2 - 5 } Penyapihan & Lebih & Baik & Kurang & Buruk \\
& 6 & 15 & 37 & 10 & 68 \\
\hline Tidak Tepat & 7 & 11 & 5 & 5 & 28 \\
Tepat & 13 & 26 & 42 & 15 & 96 \\
\hline Total & & & & &
\end{tabular}


Karena pada tabel silang di atas terdapat 2 cell yang tidak memenuhi ekspansi harapan maka dapat digabung menjadi 2 cell sebagai berikut :

Tabel 7. Tabulasi Silang Hubungan Riwayat Usia Penyapihan dengan Status Gizi Anak Usia 24-36 Bulan

\begin{tabular}{lccc}
\hline & \multicolumn{2}{c}{ Status Gizi } & Total \\
$\begin{array}{l}\text { Riwayat Usia } \\
\text { Penyapihan }\end{array}$ & Gizi Baik & Gizi Kurang & \\
& & & \\
\hline Tidak Tepat & 21 & 47 & 68 \\
Tepat & 18 & 10 & 28 \\
\hline Total & 39 & 57 & 96 \\
\hline
\end{tabular}

Dari Tabel di atas didapatkan ibu yang melakukan penyapihan tidak tepat dengan status gizi kurang sebanyak $10(10,4 \%)$, status gizi normal 18 (18,75\%). Sedangkan ibu yang melakukan penyapihan tepat waktu dengan status gizi normal sebanyak 21(21,87\%), status gizi kurang 47 (48,9\%). Dari hasil perhitungan Chi Square dengan taraf kesalahan 5\% dan $\mathrm{dk}=1$, maka $\mathrm{x}^{2}$ hitung 9,12 lebih besar dari pada harga $x^{2}$ tabel yaitu 3,481 dengan hasil uji keeratan hubungan sebesar 0,295 sehingga ada hubungan antara riwayat usia penyapihan dengan status gizi anak usia 24-36 bulan dengan kekuatan hubungan rendah atau lemah tapi pasti.

Hal ini sejalan dengan penelitian yang dilakukan Jessica dkk di Kecamatan Ratahan Kabupaten Minahasa Tenggara bahwa terdapat hubungan antara riwayat pemberian ASI dengan status gizi berdasarkan indeks BB/TB padaanak usia 24-59 bulan. ${ }^{5}$ Penelitian oleh Masyudi dkk juga menyimpulkan bahwa pola asuh yang kurang baik serta cepatnya usia penyapihan berdampak terhadap tingginya kasus gizi kurang pada balita di Kecamatan Muara Batu, Aceh Utara. ${ }^{6}$

Penyapihan adalah suatu proses yang memungkinkan bayi dapat mengkonsumsi makanan orang dewasa. Penyapihan bisa meningkatkan risiko infeksi, terutama penyakit diare. Hal ini dikarenakan bayi kurang mengonsumsi ASI yang mengandung faktor anti - infeksi. Sebagian ibu tidak menyapih anak sebelum ia berusia enam bulan, dan dapat berlangsung hingga berumur lebih dari dua tahun atau empat tahun.
Namun, sebagian besar masyarakat menyapih anak lebih awal. ${ }^{7}$

Sebesar 70,84 \% Ibu yang memiliki anak usia 24-36 bulan di Posyandu Aster melakukan penyapihan yang tidak tepat pada waktunya dengan alasan anaknya rewel dan di anjurkan oleh keluarganya. Anak yang menangis di anggap mereka lapar dan meminta makan padahal belum waktunya untuk dilakukan penyapihan. Mereka beranggapan juga jika anak yang disapih dan diberikan makanan pendamping pertumbuhannya akan lebih cepat dan bagus. Proses penyapihan ini di pengaruhi oleh beberapa faktor diantaranya kurang pengetahuan ibu tentang manfaat dan akibat jika anak tidak menerima cukup ASI, produksi ASI yang kurang lancar dan kesibukan ibu dalam bekerja.

Berdasarkan penelitian yang telah di lakukan di Posyandu Aster sebagian kecil anak yang status gizi lebih yaitu sebanyak 13(13,54\%), baik sebanyak 26 (27,08\%), kurang sebanyak $42(43,75 \%)$, buruk sebanyak $15(15,62 \%)$. Status gizi anak disini diukur berdasarkan WHO yang terdiri dari status gizi lebih, status gizi baik, status gizi kurang dan status gizi buruk. Status gizi adalah ekspresi dari keadaan keseimbangan dalam bentuk variabel tertentu atau dikatakan bahwa status gizi merupakan indikator baik buruknya penyediaan makanan sehari-hari. Faktor-faktor yang mempengaruhi status gizi adalah faktor ekstrinsik dan intrinsik. Faktor ekstrinsik meliputi menyusui dan konsumsi ASI, penyakit, umur, status pendidikan, dan status ekonomi. Menurut hasil penelitian setengah dari jumlah keseluruhan anak di Posyandu Aster berstatus gizi kurang karena ibu melakukan penyapihan yang tidak tepat pada waktunya berasal dari keluarga yang berstatus pendidikan SD dan SMP karena mereka tidak tahu kapan harus melakukan penyapihan dan memberikan konsumsi makanan yang sesuai dan bernilai gizi tinggi. Dimana pengetahuan juga dipengaruhi oleh pendidikan. Semakin tinggi pendidikan ibu maka semakin luas pengetahuannya.

Berdasarkan analisa data secara manual didapatkan bahwa harga $\mathrm{x}^{2}$ hitung sebesar 9,12 dan $\mathrm{x}^{2}$ tabel dengan taraf signifikasi 5\% sebesar 
3,481. Sehingga hitung lebih besar dari harga $\mathrm{x}^{2}$ tabel. Sedangkan dari hasil uji Koefsien Kontingensi didapatkan interval nilai sebesar 0,295 dengan kekuatan hubungan rendah atau lemah tapi pasti sehingga ada hubungan riwayat usia penyapihan dengan status gizi anak usia 2436 bulan.

Dari fakta di atas, peneliti telah membuktikan bahwa terdapat faktor yang dapat berpengaruh langsung terhadap status gizi anak yaitu riwayat usia penyapihan. Kebutuhan gizi anak dapat ditentukan oleh usia anak, jenis kelamin anak, aktivitas anak dan berat badan. Oleh karena itu antara asupan zat gizi dan pengeluarannya harus ada keseimbangan sehingga diperoleh status gizi yang baik.

Dampak penyapihan yang terlalu dini diantaranya mempengaruhi gizi yang mengakibatkan malnutrisi pada anak, insiden penyakit infeksi terutama diare meningkat, mengalami reaksi alergi yang mengaibatkan diare, muntah, ruam karena reaksi imun. ${ }^{8}$ Waktu penyapihan adalah masalah yang paling kritis karena pada masa ini terjadi masa transisi dari ASI yang pada umumnya bayi cepat dan mudah terkena gangguan gizi yang dapat mempengaruhi pertumbuhan.

Pentingnya penyuluhan secara terpadu dari berbagai sektor baik dalam skala luas yaitu dengan melalui media cetak dan dengan organisasi kemasyarakatan dan pemerintah, maupun dalam skala sempit di tingkat desa dengan melalui PKK yang diintegrasikan dalam pelaksanaan posyandu, juga pengetahuan kader kesehatan perlu ditingkatkan dan disegarkan secara berkala agar pengetahuan mereka dapat dipakai untuk memperbaiki kekeliruan yang dilaksanakan para ibu dalam pemberian ASI sekaligus proses penyapihan- nya.

Dari hasil penelitian setengah dari keseluruhan anak di Posyandu Aster disapih tidak tepat waktu dengan status gizi kurang dengan pendidikan terakhir ibu pendidikan dasar karena ibu tidak mengetahui kapan saatnya anak mereka disapih dan kapan saat yang tepat diberikan makanan pendamping. Karena setiap anak memiliki fungsi pencernaan yang berbedabeda sehingga dapat mempengaruhi status gizi masing-masing anak tersebut.

\section{SIMPULAN DAN SARAN}

Berdasarkan hasil penelitian mengenai Hubungan Riwayat Usia Penyapihan dengan Status Gizi Usia 24-36 Bulan dapat disimpulkan bahwa :

a. Riwayat penyapihan anak usia 24-36 bulan di Posyandu Aster di sebagian besar tidak tepat waktu

b. Status gizi usia 24-36 bulan di Posyandu Aster setengahnya gizi kurang

c. Ada hubungan riwayat usia penyapihan dengan status gizi anak usia 24-36 bulan dengan kekuatan hubungan rendah/ lemah tapi pasti di Posyandu Aster.

Orang tua hendaknya tidak mengambil keputusan untuk menyapih anaknya pada usia kurang dari 2 bulan karena dapat mempengaruhi status gizi anak. Bagi ibu khususnya, dapat dijadikan sarana untuk meningkatkan wawasan mengenai pertumbuhan anak yang dapat dipantau melalui status gizi dan sesuai tahap perkembangannya dalam rangka mencetak anak yang memiliki pertumbuhan dan perkembangan yang optimal. Saran bagi peneliti selanjutnya perlu dilakukan penelitian lebih lanjut dengan variabel yang lain (pemberian MP-ASI, ASI ekslusif, dan lain-lain) serta jumlah sampel lebih besar untuk lebih mendalam tentang faktor lain (lingkungan, sosial ekonomi, pola asuh balita dan lain-lain) yang berhubungan dengan status gizi

\section{UCAPAN TERIMA KASIH}

Peneliti mengucapkan terima kasih kepada semua pihak yang telah membantu terselesaikannya penelitian ini, baik pada saat proses permohonan ijin penelitian dan saat pengambilan data penelitian.

\section{REFERENSI}

1. Hanafi,Y. 2012. Peningkatan Kecerdasan Anak Melalui Pemberian ASI dalam AlQuran. Mutawâtir: Jurnal Keilmuan Tafsir Hadis. 2 (1), 27-45.

2. Naanyu, V. 2008. African Journal of Reproductive Health: www.journals.co.za

3. Dinas Kesehatan Provinsi Jawa Timur. 2018. Buku Profil Kesehatan Provinsi Jawa Timur. Surabaya: Dinas Kesehatan Provinsi Jawa Timur 
4. Riset Kesehatan Dasar (Riskesdas).2018. Badan Penelitian dan Pengembangan Kesehatan Kementerian RI Tahun 2018. Jakarta : Kementerian Kesehatan RI

5. Jessica, dkk. 2018. Hubungan Antara Riwayat Pemberian ASI dengan Status Gizi pada Anak Usia 24-59 Bulan di Kecamatan Ratahan Kabupaten Minahasa Tenggara. Manado : Fakultas Kesehatan Masyarakat Universitas Sam Ratulangi

6. Masyudi. 2019. Dampak pola asuh dan usia penyapihan terhadap status gizi balita indeks BB/U. Banda Aceh: Universitas Serambi Mekkah

7. Prasetyono, DS. 2009. Buku Pintar ASI Ekslusif. Pengenalan Praktek Dan Kemanfaatannya. Yogyakarta: Diva Press

8. Nugroho, Taufan. 2011. Asuhan Keperawatan Maternitas, Anak, Bedah, Penyakit Dalam. Yogyakarta : Nuha Medika 